\title{
Fission track dates of Mandi granite and adjacent tectonic units in Kulu-Beas valley, NW Himalaya, India
}

\author{
Monika Walia ${ }^{\mathrm{a}}$, Tsanyao Frank Yang ${ }^{\mathrm{a}, *}$, Tsung-Kwei Liu ${ }^{\mathrm{a}}$, Ravindra Kumar ${ }^{\mathrm{b}}$, Ling Chung ${ }^{\mathrm{a}}$ \\ ${ }^{a}$ Department of Geosciences, National Taiwan University, Taipei, Taiwan \\ ${ }^{\mathrm{b}}$ Centre of Advanced Study in Geology, Panjab University, Chandigarh, India
}

\begin{abstract}
We present zircon fission track (FT) ages from the lower parts of the Higher Himalayan crystalline (HHC) ranging from 3.9 to $4.3 \mathrm{Ma}$ and apatite FT age as $1.9 \pm 0.4 \mathrm{Ma}$. Combined with previous radiometric dates, these ages provide the low temperature data for the area and enable us to draw temperature-time plot which shows significant increase in cooling rates from $25^{\circ} \mathrm{C} / \mathrm{Ma}$ in Oligocene and $4{ }^{\circ} \mathrm{C} / \mathrm{Ma}$ in Miocene to about $64^{\circ} \mathrm{C} / \mathrm{Ma}$ during Pliocene. For the Mandi granite, the zircon FT ages range from 3.9 to $4.9 \mathrm{Ma}$ while apatite FT obtained is $2.8 \pm 0.5 \mathrm{Ma}$. The rapid Pliocene exhumation is characterized by a rapid increase in cooling rates from $\sim 3.4^{\circ} \mathrm{C} / \mathrm{Ma}$ in Miocene to $\sim 77^{\circ} \mathrm{C} / \mathrm{Ma}$ after 5.0 Ma. Our results confirm the rapid Pliocene to Pleistocene cooling of rocks of Kulu-Beas valley similar to that of the neighboring units from the frontal parts of HHC.
\end{abstract}

(c) 2008 Elsevier Ltd. All rights reserved.

Keywords: Fission track dating; NW Himalaya; Exhumation

\section{Introduction}

The ongoing collision between Indian Plate and the Eurasian Plate causes deformation, crustal thickening and surface uplift of the Himalayan orogen. Various thrust zones divide the Himalayan orogen into its major tectonic units (Fig. 1a). From north to south these are: Trans-Himalaya, Indus Tsangpo suture zone (also known as Indus-Yarlung suture zone), Higher Himalaya, Lesser Himalaya and Sub-Himalaya (Gansser, 1964). Thrusting within the Himalaya as a response to the collision is considered to have propagated from north to south: the northern most suture zone was active at ca. $50-55 \mathrm{Ma}$ (Searle et al., 1990), the main central thrust (MCT) was active at ca. 20-22 Ma (Hubbard and Harrison, 1989) and the main boundary thrust (MBT) was active after 10 Ma (Meigs et al., 1995). Moreover, south-directed thrusts including the MCT and the MBT accommodated about $1400 \mathrm{~km}$ of north-south

\footnotetext{
* Corresponding author. Tel.: +88623366 5874; fax: +886223636095.

E-mail address: tyyang@ntu.edu.tw (T.F. Yang).
}

shortening between the two continents (Burbank et al., 1996). Immense size and high elevation of Himalaya-Tibet orogen are considered to have played a critical role in controlling the global climate change. This climate change is reported to have affected erosion rates (Yin and Harrison, 2000).

The Himalayan metamorphic belt (HMB) is the Proterozoic Indian crust which was deformed and remobilized in Cenozoic due to the collision. It is bounded to the south by the MCT and to the north by the South Tibetan detachment system. Exhumation of this metamorphic belt was speeded up after $\sim 20 \mathrm{Ma}$. HMB is intruded by numerous Paleozoic granitoids. One of these is the Mandi granite of batholithic dimensions.

Many Ar-Ar and FT dates are available in Tibetan plateau to demonstrate a rapid cooling history in Miocene (e.g., Yang et al., 1999; Lee et al., 2003). However, very little published geochronological data pertain to the low temperature thermal history of the Mandi granite and its adjoining units in HMB. Here we present fission track (FT) ages of zircon and apatite along a section crossing major structures like MBT and HMB. Interpreting the spatial age variation in comparison with the data available from neighboring areas strengthens the relation of tectonic activity on erosion. 

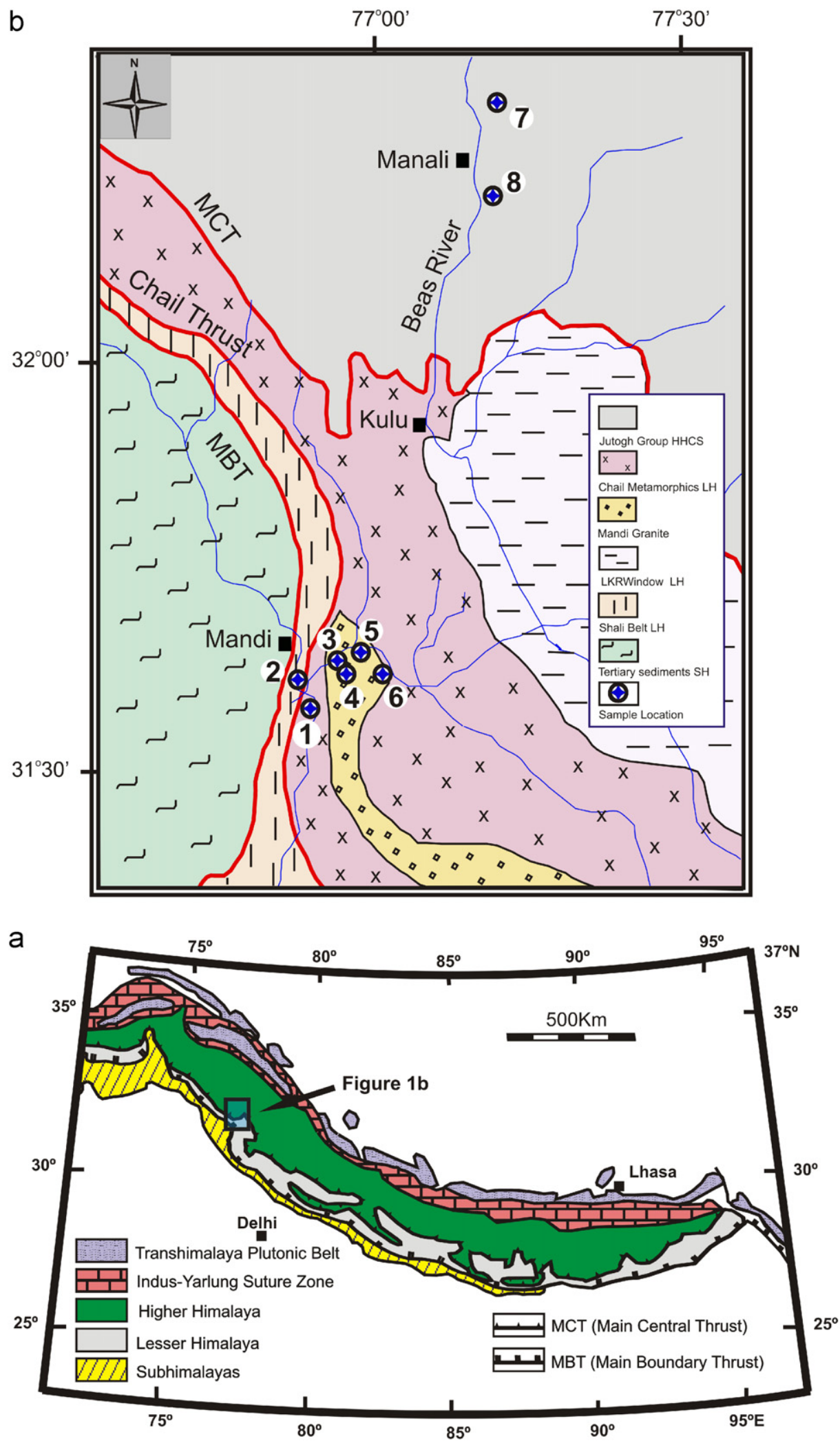

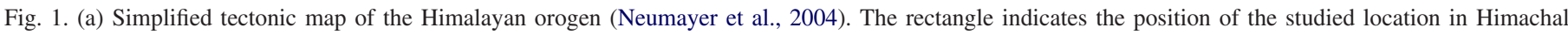
Pradesh enlarged in (b). (b) Regional map of the Kulu-Beas valley (reproduced from Pandey et al., 2004) with sample localities marked as numbers 1-8. 


\section{Regional geology}

The investigated area lies in the Kulu-Beas valley in NW Himalaya, Himachal Pradesh, India. Shali belt of Proterozoic metavolcanics-quartzite-dolomite is thrust over the SubHimalaya along MBT (Fig. 1b). This belt is bounded by the Chail thrust, a splay of the MCT, along its northeastern boundary. Further north of the Chail thrust is the HMB comprising Jutogh nappe belonging to Higher Himalayan crystallines (HHC). Various units in the studied area from north to south are (Fig. 1b):

HHC: The MCT is a shear zone of a few kilometers to $>10 \mathrm{~km}$ thickness. The hanging wall of the MCT is the High Himalayan slab of Indian Plate (Fig. 1). The mineral assemblages quartz + plagioclase + muscovite + biotite \pm garnet \pm staurolite \pm kyanite are typical of the medium-pressure, high temperature metamorphism.

Mandi granite: Foliated and non-foliated granitic rocks of Mandi granite belong to the Lesser Himalaya. The unit is intruded into Chail metamorphics (Gupta, 1970) and contains quartz, plagioclase, muscovite, biotite as the major constituents and epidote, monazite, zircon, apatite and tourmaline are accessory minerals. The intrusive body is considered to be of Paleozoic age based on the $\mathrm{Rb}-\mathrm{Sr}$ whole rock isochron age of $545 \pm 12$ Ma (Mehta, 1977).

$M B T$ : A shuppen zone, i.e., a zone of parallel thrusts, marks the contact between the Lesser Himalaya and the underlying Siwalik formation and is termed as the MBT. The slip on the MBT began at around $11 \mathrm{Ma}$ as reported by Burbank et al.
(1996) based on magnetostratigraphy records of the Himalayan foreland.

\section{FT analyses}

Apatite crystals were mounted in epoxy resin and polished. Tracks were revealed by etching with $4 \% \mathrm{HNO}_{3}$ at $21 \pm 1{ }^{\circ} \mathrm{C}$ for $25 \pm 2 \mathrm{~s}$. U-free muscovite was used as external detector attached to each sample mount. Zircon crystals were mounted in teflon sheets. Etching was done using $\mathrm{KOH}-\mathrm{NaOH}-\mathrm{LiOH}$ eutectic solution for $7-8 \mathrm{~h}$ at $230 \pm 5^{\circ} \mathrm{C}$. Dosimeters used with apatite and zircon were NBS-612 and NBS-610, respectively. The samples were irradiated at Hsing-Hua University, Hsinchu, Taiwan. After irradiation, muscovite sheets were etched using $48 \% \mathrm{HF}$ for $20 \mathrm{~min}$ at room temperature. Counting was performed at $2500 \times$ total magnification (oil immersion). Grainby-grain and external detector method with error of $1 \sigma$ are considered for age calculations. The detailed analytical method adopted is given in Yang et al. (1995, 2003).

\section{Results and discussion}

The analytical data of zircon and apatite samples are presented in Table 1. Ages were calculated using the Binomfit program (Brandon, 1996). The probability-density plots are given in Fig. 2. For calculating the cooling rates, closure temperatures of $110^{\circ} \mathrm{C}$ for apatite, $250^{\circ} \mathrm{C}$ for zircon, $300^{\circ} \mathrm{C}$ for $\mathrm{Rb}-$ Sr biotite and $500^{\circ} \mathrm{C}$ for $\mathrm{Rb}-\mathrm{Sr}$ muscovite (Lal et al., 1999) have been considered. The slope of each line segment in the plots provides the cooling rates for different time periods.

Table 1

Fission track analytical data of this study

\begin{tabular}{|c|c|c|c|c|c|c|c|c|c|c|c|c|c|c|}
\hline No. & Sample & Location & $\begin{array}{l}\text { Altitude } \\
\text { (ft.) }\end{array}$ & $\begin{array}{l}\text { Rock } \\
\text { type }\end{array}$ & $\begin{array}{l}\text { Mineral } \\
\text { dated }\end{array}$ & $N$ & $\rho_{\mathrm{s}}$ & $N_{\mathrm{s}}$ & $\rho_{\mathrm{i}}$ & $N_{\mathrm{i}}$ & $\mathrm{U}(\mathrm{ppm})$ & $\begin{array}{l}\chi^{2} \text { age } \\
(\mathrm{Ma} \pm 1 \sigma)\end{array}$ & $\begin{array}{l}\text { Central age } \\
(\mathrm{Ma} \pm 1 \sigma)\end{array}$ & $\begin{array}{l}P \\
\left(\chi^{2}\right) \%\end{array}$ \\
\hline 1 & BM 1 & $\begin{array}{l}\mathrm{N} 31^{\circ} 40^{\prime} 54^{\prime \prime} \\
\mathrm{E} 76^{\circ} 56^{\prime} 51^{\prime \prime}\end{array}$ & 2614 & Quartzite & Zircon & 27 & 2.54 & 1906 & 1.01 & 754 & 540 & $6.4 \pm 0.6$ & $9.2 \pm 1.7$ & $<1$ \\
\hline 2 & BM 2 & $\begin{array}{l}\mathrm{N} 31^{\circ} 41^{\prime} 54^{\prime \prime} \\
\mathrm{E} 76^{\circ} 56^{\prime} 19^{\prime \prime}\end{array}$ & 2572 & Quartzite & Zircon & 21 & 1.25 & 359 & 1.17 & 335 & 626 & $4.1 \pm 0.4$ & $4.1 \pm 1.0$ & 1.5 \\
\hline 3 & MG 1 & $\begin{array}{l}\mathrm{N} 31^{\circ} 42^{\prime} 08^{\prime \prime} \\
\mathrm{E}^{\prime} 6^{\circ} 58^{\prime} 35^{\prime \prime}\end{array}$ & 2560 & $\begin{array}{l}\text { Gneissic } \\
\text { granite }\end{array}$ & Zircon & 28 & 1.31 & 622 & 1.19 & 566 & 639 & $3.9 \pm 0.3$ & $3.9 \pm 0.9$ & $<1$ \\
\hline 4 & MG 2 & $\begin{array}{l}\mathrm{N} 31^{\circ} 42^{\prime} 10^{\prime \prime} \\
\mathrm{E} 76^{\circ} 58^{\prime} 37^{\prime \prime}\end{array}$ & 2541 & Granite & Apatite & 19 & 0.045 & 102 & 0.429 & 978 & 36.5 & $1.8 \pm 0.3$ & $2.8 \pm 0.5$ & $<1$ \\
\hline 5 & MG 3 & $\begin{array}{l}\mathrm{N} 31^{\circ} 42^{\prime} 38^{\prime \prime} \\
\mathrm{E} 76^{\circ} 59^{\prime} 32^{\prime \prime}\end{array}$ & 2571 & Granite & Zircon & 14 & 1.70 & 529 & 1.43 & 443 & 767 & $3.0 \pm 0.4$ & $4.9 \pm 1.3$ & $<1$ \\
\hline 6 & MG 5 & $\begin{array}{l}\mathrm{N} 31^{\circ} 39^{\prime} 45^{\prime \prime} \\
\mathrm{E} 77^{\circ} 02^{\prime} 47^{\prime \prime}\end{array}$ & 2965 & Granite & Zircon & 13 & 4.06 & 652 & 3.15 & 506 & 1692 & $5.0 \pm 0.4$ & $4.9 \pm 1.1$ & 2.2 \\
\hline 7 & MNL 1 & $\begin{array}{l}\mathrm{N} 32^{\circ} 18^{\prime} 23^{\prime \prime} \\
\mathrm{E} 77^{\circ} 10^{\prime} 58^{\prime \prime}\end{array}$ & 7060 & $\begin{array}{l}\text { Granitic } \\
\text { gneiss }\end{array}$ & Zircon & 33 & 2.04 & 2034 & 2.00 & 2000 & 1064 & $3.8 \pm 0.2$ & $3.9 \pm 0.8$ & $<1$ \\
\hline 7 & MNL 1 & $\begin{array}{l}\mathrm{N} 32^{\circ} 18^{\prime} 23^{\prime \prime} \\
\mathrm{E} 77^{\circ} 10^{\prime} 58^{\prime \prime}\end{array}$ & 7060 & $\begin{array}{l}\text { Granitic } \\
\text { gneiss }\end{array}$ & Apatite & 21 & 0.039 & 38 & 0.52 & 496 & 44.1 & $1.9 \pm 0.4$ & $1.9 \pm 0.4$ & 22.2 \\
\hline 8 & MNL 3 & $\begin{array}{l}\mathrm{N} 32^{\circ} 10^{\prime} 43^{\prime \prime} \\
\mathrm{E} 77^{\circ} 10^{\prime} 51^{\prime \prime}\end{array}$ & 4960 & $\begin{array}{l}\text { Granitic } \\
\text { gneiss }\end{array}$ & Zircon & 24 & 2.58 & 4116 & 2.28 & 3637 & 1224 & $3.7 \pm 0.2$ & $4.3 \pm 0.9$ & $<1$ \\
\hline
\end{tabular}

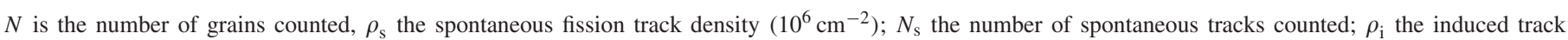

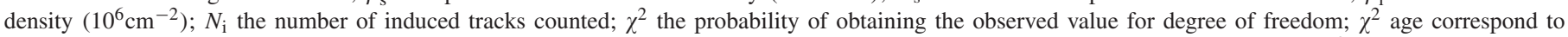

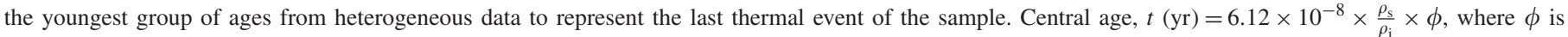
the neutron dose, $\phi$ zircon $=1.25 \times 10^{14}, \phi$ apatite $=0.65 \times 10^{14}$. 

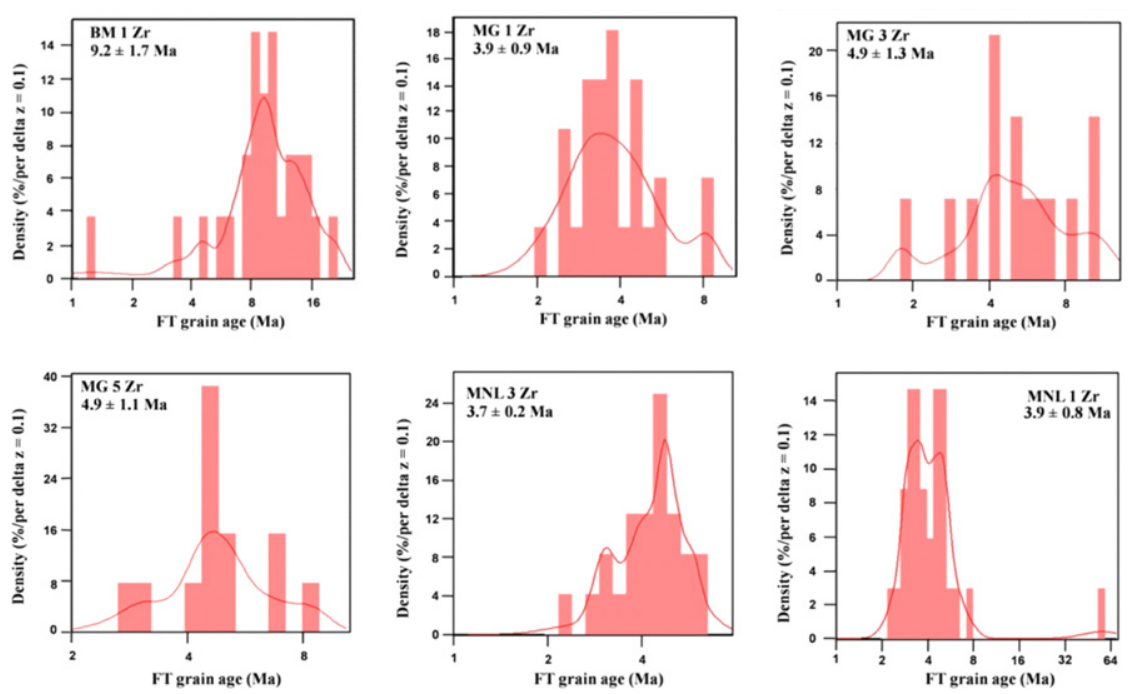

Fig. 2. Probability-density plots of some of the samples. The mentioned ages are the Central ages. All samples show similar central and $\chi^{2}$ ages with the exception of one sample from the MBT zone. Suffix Zr has been used for zircon FT age.

The zircon FT ages from the HHC are $3.9 \pm 0.8$ and $4.3 \pm 0.9 \mathrm{Ma}$ and apatite FT age is $1.9 \pm 0.4 \mathrm{Ma}$. Zircon FT ages from Mandi granite range from $4.9 \pm 1.1$ to $3.9 \pm 0.9 \mathrm{Ma}$, while apatite FT age is $2.8 \pm 0.5 \mathrm{Ma}$. A quartzite sample from the MBT zone has yielded zircon FT age as 4.1 $\pm 1.0 \mathrm{Ma}$ and a zircon FT age from the hanging wall of MBT is $9.2 \pm 1.7 \mathrm{Ma}$.

Very young apatite and zircon FT ages reported in the previous studies from the Sutlej valley lie in the frontal parts of HHC. The area is characterized by very high precipitation due to high topography and lies in the zone of high erosion. The FT ages from this study point towards wide spread deep erosion in NW Himalaya. Monsoonal precipitation controlled by topography exerts a strong control on erosional processes mainly due to landslides, deep fluvial incision and sediment removal (Thiede et al., 2004).

For the HHC near Manali town, Himachal Pradesh, the newly reported zircon and apatite FT ages along with the $\mathrm{Rb}-\mathrm{Sr}$ biotite age of $16.7 \pm 0.5 \mathrm{Ma}$ and $\mathrm{Rb}-\mathrm{Sr}$ muscovite age of $26.5 \pm 1 \mathrm{Ma}$ (Mehta, 1977) help in determining the cooling rates (Fig. 3). These are $25^{\circ} \mathrm{C} / \mathrm{Ma}$ for late Oligocene to midMiocene, decreasing to about $4{ }^{\circ} \mathrm{C} / \mathrm{Ma}$ during mid-Pliocene and again increasing during Pliocene to about $64^{\circ} \mathrm{C} / \mathrm{Ma}$.

New FT ages along with $\mathrm{Rb}-\mathrm{Sr}$ biotite ages $(18.6 \pm 0.5$ and $19.3 \pm 0.5 \mathrm{Ma}$ ) reported by Mehta (1977) for Mandi granite have been used in determining the cooling rates (Fig. 3). From the temperature-time plot it is evident that during early Miocene to early Pliocene this granitic body had a slow cooling rate of $3.4^{\circ} \mathrm{C} / \mathrm{Ma}$, which increased to about $77^{\circ} \mathrm{C} /$ Ma during Pliocene. A zircon FT age reported in this article from MBT zone in NW Himalaya is $4.1 \pm 1.0 \mathrm{Ma}$. Apatite FT ages from MBT zone in the Western Himalaya, Pakistan (Meigs et al., 1995), in the range from $8.2 \pm 2.0$ to $9.6 \pm 1.2 \mathrm{Ma}$ have been suggested to indicate activation of MBT in middle-late Miocene. Although the data is too sparse to define its age precisely, it seems likely that the thrust was still active in NW Himalaya until late Miocene-Pliocene.
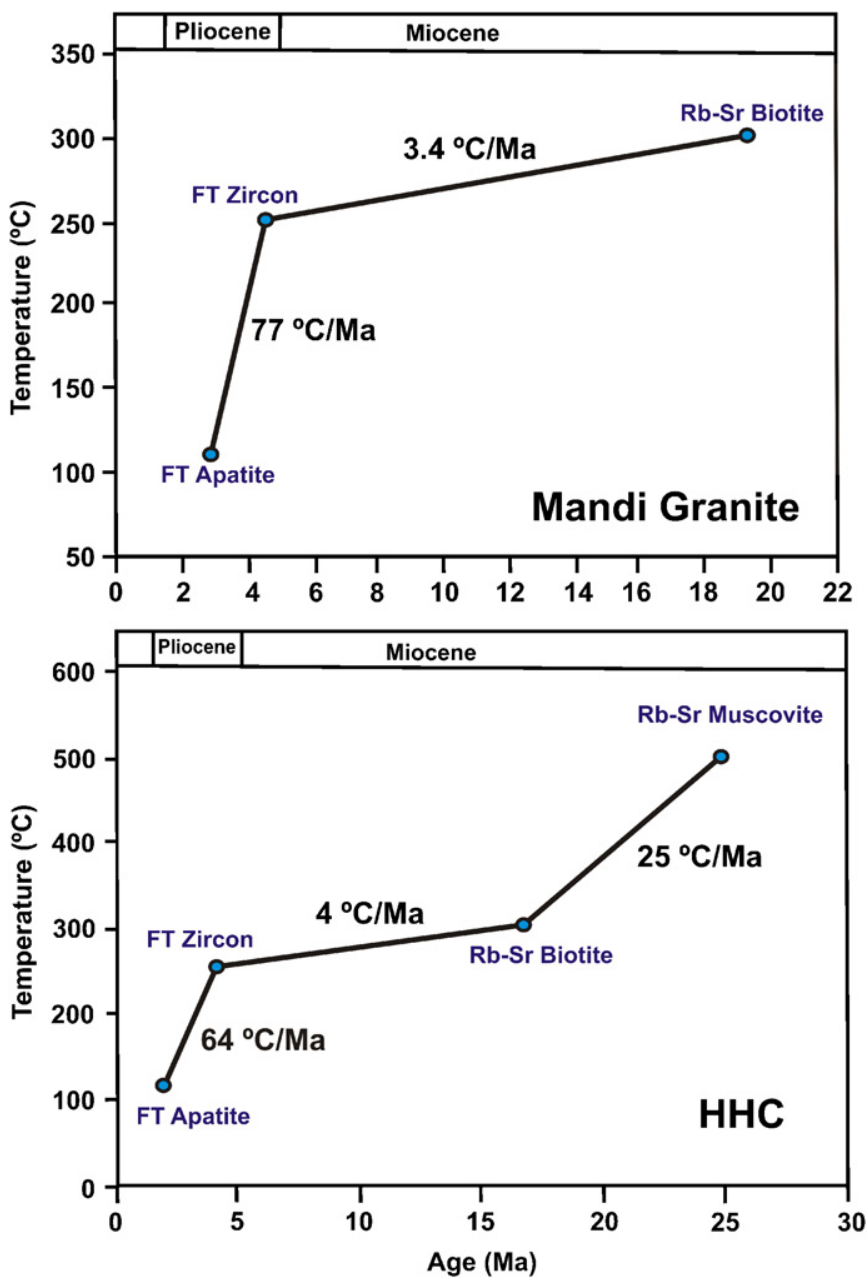

Fig. 3. Temperature-time plot for the rocks of Higher Himalayan Crystallines (HHC) and Mandi granite. There is a significant increase in cooling rates after the zircon closure temperature. The numbers in the graph denote the cooling rates. 


\section{Conclusions}

Cooling rates of $\sim 64^{\circ} \mathrm{C} / \mathrm{Ma}$ from the lower parts of the High Himalaya Crystallines (HHC) and $\sim 77^{\circ} \mathrm{C} / \mathrm{Ma}$ from the Lesser Himalaya (Mandi granite) obtained from the new FT data added to the previous data give evidence for increased exhumation rates during Pliocene in this part of the Himalaya. The obtained young ages may be the result of rapid erosion coupled with high precipitation. The zone of high erosion related to high regional precipitation lies in the frontal part of HHC as reported from Sutlej valley (Thiede et al., 2004). The young rapid Pliocene-Pleistocene cooling of the Mandi granite is similar to the rapid cooling of Bandal granitic gneiss intrusive body of Larji Kulu-Rampur Window, as evidenced by Jain et al. (2000). Young zircon FT age obtained from the MBT zone indicates that the thrust zone was cooled through $\sim 250^{\circ} \mathrm{C}$ at around $4 \mathrm{Ma}$.

\section{Acknowledgment}

The authors would like to thank Mr. C.C. Fu for his help during field work. Prof. C.-H. Chen and Prof. S.L. Chung are thanked for their guidance and fruitful discussions. Two anonymous reviewers gave critical comments and improved the manuscript. This research work was funded by National Science Council (TFY/NSC 94-2116-M-002-010 and NSC 952116-M-002-009).

\section{References}

Brandon, M.T., 1996. Probability density plot for fission track grain-age samples. Radiat. Meas. 26, 663-676.

Burbank, D.W., Beck, R.A., Mulder, T., 1996. The Himalayan foreland basin. In: Yin, A., Harrison, T.M. (Eds.), The Tectonics of Asia. Cambridge University Press, New York, pp. 149-188.

Gansser, A., 1964. Geology of the Himalaya. Interscience Publication. Wiley, London. 289pp.

Gupta, L.N., 1970. Petrology of the metabasites and associated rocks northeast of Mandi (H.P.). J. Indian Geosci. Assoc. 12, 9-14.

Hubbard, M.S., Harrison, T.M., 1989. ${ }^{40} \mathrm{Ar} /{ }^{39} \mathrm{Ar}$ age constraints on deformation and metamorphism in the MCT zone and Tibetan slab, eastern Nepal Himalaya. Tectonics 8, 865-880.
Jain, A.K., Kumar, D., Sigh, S., Kumar, A., Lal, N., 2000. Timing, quantification and tectonic modeling of Pliocene-quaternary movements in the NW Himalaya: evidence from fission track dating. Earth Planet. Sci. Lett. 179, 437-451.

Lal, N., Mehta, Y.P., Kumar, A., Jain, A.K., 1999. Cooling and exhumation history of the Mandi granite and adjoining tectonic units, Himachal Pradesh, and estimation of closure temperature from external surface of zircon. In: Jain, A.K., Manickavasagam, R.M. (Eds.), Geodynamics of the NW Himalaya, vol. 6. Gondwana Research Group Memoir, pp. 207-216.

Lee, H.Y., Chung, S.L., Wang, J.R., Wen, D.J., Lo, C.H., Yang, T.F., Zhang, Y., Xie, Y., Lee, T.Y., Wu, G., Ji, J., 2003. Miocene Jiali faulting and its implications for Tibetan tectonic evolution. Earth Planet. Sci. Lett. 205, 185-194.

Mehta, P.K., 1977. Geochronology of the Kulu-Mandi belt: its implications for the Himalayan tectogenesis. Geol. Rundsch. 6, 156-188.

Meigs, A.J., Burbank, D.W., Beck, R.A., 1995. Middle-late Miocene ( $>10 \mathrm{Ma}$ ) formation of the main boundary thrust in the western Himalaya. Geology 23, 423-426.

Neumayer, J., Wisemayr, G., Janda, C., Grasemann, B., Draganits, E., 2004. Eohimalayan fold and thrust belt in the NW-Himalaya (Lingti-Pin Valleys): shortening and depth to detachment calculation. Austr. J. Earth Sci. 95/96, $28-36$.

Pandey, A.K., Sachen, H.K., Virdi, N.S., 2004. Exhumation history of a shear zone constrained by microstructural and fluid inclusion technique: an example from the Satluj valley, NW Himalaya, India. J. Asian Earth Sci. 23, 391-406.

Searle, M.P., Parrish, R.R., Tirrul, R., Rex, D.C., 1990. Age of crystallization of the K2 gneiss in the Baltoro Karakorum. J. Geol. Soc. 147, 603-606.

Thiede, R.C., Bookhagen, B., Arrowsmith, J.R., Sobel, E.R., Strecker, M.R., 2004. Climate control on rapid exhumation along the Southern Himalayan Front. Earth Planet. Sci. Lett. 222, 791-806.

Yang, T.F., Tien, J.L., Chen, C.-H., Lee, T., Punongbayan, R.S., 1995. Fissiontrack dating of volcanics in the northern part of the Taiwan-Luzon arc: eruption ages and evidence for crustal contamination. J. SE Asian Earth Science 11(2), 81-93.

Yang, T.F., Wang, J.R., Lo, C.H., Chung, S.L., Tien, J.L., Xu, R., Deng, W.M., 1999. The thermal history of the Lhasa Block, South Tibetan Plateau based on FTD and Ar-Ar dating. Radiat. Meas. 31, 627-632.

Yang, T.F., Chen, C.-H., Tien, R.L., Song, S.R., Liu, T.K., 2003. Remnant magmatic activity in the Coastal Range of East Taiwan after arc-continent collision: fission-track data and ${ }^{3} \mathrm{He} /{ }^{4} \mathrm{He}$ ratio evidence. Radiat. Meas. 36, 343-349.

Yin, A., Harrison, T.M., 2000. Geologic evolution of the Himalayan-Tibetan orogen. Ann. Rev. Earth Planet. Sci. 28, 211-280. 